УДк 633.15+631.81.095.337

DOI 10.36461/NP.2020.54.1.002

\title{
ВЛИЯНИЕ ПРЕПАРАТОВ С КРЕМНИЕМ НА ФОРМИРОВАНИЕ УРОЖАЙНОСТИ КУКУРУЗЫ
}

С. А. Семина, доктор с.-х. наук, професссор; И. В. Гаврюшина, канд. биол. наук, доцент; Е. В. Никулина, аспирант

Федеральное государственное образовательное учреждение высшего образования «Пензенский государственный аграрный университет», Россия,

т. (8412)628-151, e-mail: seminapenza@rambler. ru

В статье представлены результаты исследований по влиянию различных видов кремнийсодержащих препаратов на формирование урожайности кукурузы в зависимости от срока некорневой обработки. Наибольший ростостимулирующий эффект отмечен при двукратной обработке посевов кукурузы НаноКремнием. Прирост по сравнению с вариантом с обработкой водой составил $33 \mathrm{~cm}$. При применении Келик Калий-Кремния более высокорослые растения сформировались при фолиарной обработке в фазу пяти листьев, прирост к варианту без препарата составил 19 см. На вариантах с применением Микровит-6 Кремний превышение высоты растений по сравнению с опрыскиванием водой составило 14-18 см. Увеличение количества развитых початков при фолиарной обработке препаратами с кремнием составило 8,1-18,7\% при небольшом преимуществе НаноКремния. Более мощные растения сформировались в вариантах с фолиарной обработкой посевов кукурузы препаратом НаноКремний в фазу пяти листьев и двукратном опрыскивании, увеличение массы одного растения, по сравнению с вариантами без препарата, составило 110-112 г или 19,722,0 \%. Более эффективной была обработка НаноКремнием в фазу пяти листьев кукурузы и двукратное применение, которые обеспечили прирост урожайности фитомассы 20,6-21,0 \% по сравнению с вариантами без препарата. Немного уступает по эфффективности препарат Микровит-6 Кремний, обеспечивший прирост урожайности зеленой массы 12,4-19,3 \%. Фолиарная обработка Келик Калий-Кремний способствовала увеличению урожайности зеленой массы на 3,7-5,7 т/га или 10,5-15,7 \%. Наибольший выход сухого вещества обеспечил вариант с двукратной обработкой посевов НаноКремнием, прирост составил 3,2 т/га.

Ключевые слова: кукуруза, кремний, биометрические показатели, зеленая масса, початки, урожайность.

\section{Введение.}

Вопросы рационального применения удобрений в настоящее время являются основой повышения урожайности кукурузы. Современные тенденции развития сельского хозяйства привели к появлению нового типа удобрений, регуляторов роста, пестицидов и антидотов широкого спектра использования, действующим веществом которых является активный кремний [1]. Основной функцией кремния в растении является увеличение устойчивости организма к неблагоприятным условиям, выражающееся в утолщении эпидермальных тканей, ускорении роста и развития корневой системы, связывании токсичных соединений и увеличении биохимической устойчивости к стрессам, снижении действия высоких температур [2]. Кремний необходим для улучшения потребления азота, фосфора и калия [3]. Он стимулирует ростовые процессы, ускоряет наступление фаз выметывания и созревания, что связано с увеличением энергии для метаболи- ческих процессов и синтеза сахаров [4, 5]. Интерес к кремнию связан с возможностью его использования в качестве экологически чистой альтернативы пестицидам, а также для повышения природной устойчивости к биотическим и абиотическим стрессам [6-7, 15]. Накопление кремния в проводящих сосудах вызывает повышение механической прочности тканей. Кремний необходим для нормального роста и развития надземных органов и корневой системы растений [8-10, 14, 16-18]. В развитии растений кукурузы можно выделить два важных этапа (критические фазы) по обеспеченности их макро- и микроэлементами: фразы 3-5 и 7-8 листьев. От наличия элементов питания в эти периоды зависит будущий урожай. Bсе микроэлементы требуются растениям в небольших дозах. Поэтому лучшим способом их внесения является некорневая подкормка, которая проводится путем опрыскивания водным раствором удобрений. При применении этого способа подкормки большинство питательных элементов по- 
падает непосредственно на поверхность листьев растения. А использование кремний содержащих препаратов, в которых кремний находится в виде наночастиц, способствует наибольшему усвоению питательных элементов растением [11]. Поэтому большой интерес представляет, ранее мало изученный, вопрос применения кремнийсодержащих удобрений на посевах кукурузы в условиях лесостепи Среднего Поволжья.

Цель исследования заключается в обосновании видов и сроков применения препаратов с кремнием на черноземе выщелоченном лесостепи Среднего Поволжья.

\section{Методика и материалы}

Исследования проводились в 2018-2019 гг. в условиях ЗАО «Константиново» Пензенского района Пензенской области на черноземе выщелоченном среднемощном среднегумусном тяжелосуглинистом на покровном карбонатном суглинке, имеющем следующую агрохимическую характеристику: содержание гумуса - 5,1-5,4 \%; $\mathrm{N}_{\text {щел }}$ $110-112 ; \mathrm{P}_{2} \mathrm{O}_{5}-108-121 ; \mathrm{K}_{2} \mathrm{O}-144-153$ мг/кг почвы; $\mathrm{pH}_{\text {сол }}-5,31-5,42$.

Полевой опыт был заложен в четырехкратной повторности в соответствии с общепринятыми методиками [12,13] по схеме: Фактор А - вид препарата: 1. Без препарата (обработка водой); 2. Келик КалийКремний (1,5 л/га); 2. НаноКремний (150 г/га); 3. Микровит-6 Кремний (0,5 л/га); фактор В - срок обработки: 5 листьев кукурузы; 7-8 листьев кукурузы; 5 листьев + 7-8 листьев кукурузы. Площадь делянки второго порядка $28 \mathrm{~m}^{2}$. Под первую предпосевную культивацию внесли минеральные удобрения в дозе $\mathrm{N}_{90} \mathrm{P}_{60} \mathrm{~K}_{40}$. Объект исследований - раннеспелый гибрид кукурузы Ладожский 191 МВ (ФАО 190). Посев проводили сеялкой Quivogne Prosem K 16 с междурядьями 70 см. Густоту стояния растений (70 тыс./га) формировали в фазе полных всходов. Предшественник - озимая пшеница по чистому пару. Некорневую обработку опытных делянок растворами препаратов проводили с помощью ранцевого опрыскивателя. Дозы препаратов взяты из рекомендаций производителя.

Анализ погодных условий 2018 г. показал, что в период посева, во второй декаде мая, температура воздуха была выше среднемноголетней, а осадков выпало 72,3\% от среднемноголетнего значения. В третьей декаде мая температура практически не отличалась от среднемноголетних значений на фоне засушливых условий. Гидротермический коэфффициент (ГТК) за месяц составил 0,39. Первая и вторая декады июня были прохладными и засушливыми,
ГТК 0,15 и 0,36 соответственно. В третьей декаде июня температура превысила среднемноголетнюю на $4,7{ }^{\circ} \mathrm{C}$ при полном отсутствии осадков. Первая и вторая декада июля были прохладными, а количество осадков было меньше среднемноголетних. Третья декада июля была жаркой, но засушливой, ГТК составил 0,33. Август был теплым при минимальном количестве осадков, ГТК составил, соответственно, по декадам, 0,25, 0,06 и 0,25. Недостаточные влагообеспеченность и количество активных температур воздуха не способствовали полной реализации потенциала гибрида и получению высокого урожая биомассы кукурузы. Посев кукурузы в 2019 г. проведен в условиях повышенных температур, но ранние сроки сева (последняя декада апреля) и хорошие запасы продуктивной влаги в почве способствовали получению быстрых и дружных всходов. Осадки в период вегетации выпадали неравномерно, но большая их часть выпала во второй декаде июля и первой декаде августа, в период активного роста и развития кукурузы, что способствовало формированию большей урожайности кукурузы, по сравнению с предыдущим годом исследования.

\section{Результаты}

Важным критерием, по которому можно судить об условиях, в которых развивается и формируется растение, является высота растения. Улучшение условий питания оказывает положительное влияние на этот морфологический признак. Как показали результаты измерений, все изучаемые препараты положительно повлияли на динамику линейного роста растений. В среднем, за два года исследований к уборке урожая наибольший ростостимулирующий эфффект отмечен при двукратной обработке посевов кукурузы НаноКремнием. Прирост, по сравнению с вариантом с обработкой водой, составил 33 см (табл.). Обработка в фразу пяти листьев привела к увеличению высоты растения на 12 см, а при опрыскивании в фразу семи-восьми листьев - на 26 см. При применении Келик Калий-Кремния более высокорослые растения сформировались при фолиарной обработке в фазу пяти листьев, прирост к варианту без препарата составил 19 см. Опрыскивание в фазу семи-восьми листьев и двукратное применение препарата способствовало увеличению высоты растения на 7-9 см. На вариантах с применением Микровит-6 Кремний превышение высоты растений по сравнению с опрыскиванием водой составило: при обработке в фазу 5 листьев - 17 см, 7-8 листьев - 14 см, двукратной фолиарной обработке - $18 \mathrm{~cm}$. 
Морфобиометрические показатели кукурузы, среднее за 2018-2019 г2.

\begin{tabular}{|c|c|c|c|c|c|}
\hline \multirow[b]{2}{*}{$\begin{array}{l}\text { Вид } \\
\text { препарата }\end{array}$} & \multirow[b]{2}{*}{ Срок обработки } & \multicolumn{2}{|c|}{ Высота } & \multirow{2}{*}{$\begin{array}{c}\text { Количество } \\
\text { початков } \\
\text { на } 100 \\
\text { растений, шт. }\end{array}$} & \multirow[b]{2}{*}{$\begin{array}{c}\text { Масса од- } \\
\text { ного рас- } \\
\text { тения, г }\end{array}$} \\
\hline & & $\begin{array}{c}\text { растений, } \\
\text { см }\end{array}$ & $\begin{array}{c}\text { прикрепления } \\
\text { нижнего по- } \\
\text { чатка, см }\end{array}$ & & \\
\hline Без препарата & 5 листьев & 202 & 53,5 & 120 & 561 \\
\hline \multirow{2}{*}{$\begin{array}{l}\text { (обработка } \\
\text { водой) }\end{array}$} & 7-8 листьев & 202 & 52,5 & 121 & 559 \\
\hline & 5 листьев + 7-8листьев & 200 & 53,0 & 123 & 560 \\
\hline \multirow{3}{*}{\begin{tabular}{|l|} 
Келик \\
Калий- \\
Кремний \\
\end{tabular}} & 5 листьев & 220 & 69,0 & 140 & 639 \\
\hline & 7-8 листьев & 210 & 68,5 & 133 & 615 \\
\hline & 5 листьев + 7-8листьев & 208 & 67,0 & 133 & 649 \\
\hline \multirow{3}{*}{$\begin{array}{l}\text { Нано } \\
\text { Кремний }\end{array}$} & 5 листьев & 213 & 71,5 & 145 & 673 \\
\hline & 7-8 листьев & 227 & 70,0 & 137 & 621 \\
\hline & 5 листьев + 7-8листьев & 234 & 80,0 & 146 & 669 \\
\hline \multirow{3}{*}{$\begin{array}{l}\text { Микровит-6 } \\
\text { Кремний }\end{array}$} & 5 листьев & 218 & 71,0 & 142 & 617 \\
\hline & 7-8 листьев & 215 & 69,0 & 142 & 636 \\
\hline & 5 листьев + 7-8листьев & 219 & 73,5 & 141 & 668 \\
\hline
\end{tabular}

При уборке урожая кукурузы очень важно, чтобы в биомассе были сохранены генеративные органы растения. Поэтому большое значение имеет высота прикрепления нижнего развитого початка. Как показали результаты исследований, все изучаемые препараты, независимо от срока применения, способствовали закладке нижнего развитого початка на большей высоте, превышающей варианты с обработкой водой на 4,0-27,0 см.

Подсчет количества початков на сто растений кукурузы показал, что в условиях вегетации 2018 г. и поздних сроках посева

применение для некорневой обработки препаратов, содержащих кремний, не привело к увеличению числа генеративных органов. Все растения сформировали по одному початку, как и при обработке растений водой. В более благоприятном по гидротермическому режиму 2019 г. все кремнийсодержащие препараты оказали положительное влияние на формирование генеративных органов, но значительной разницы по препаратам и срокам обработки не выявлено. В среднем за два года исследований прирост количества початков от фолиарной обработки препаратами с

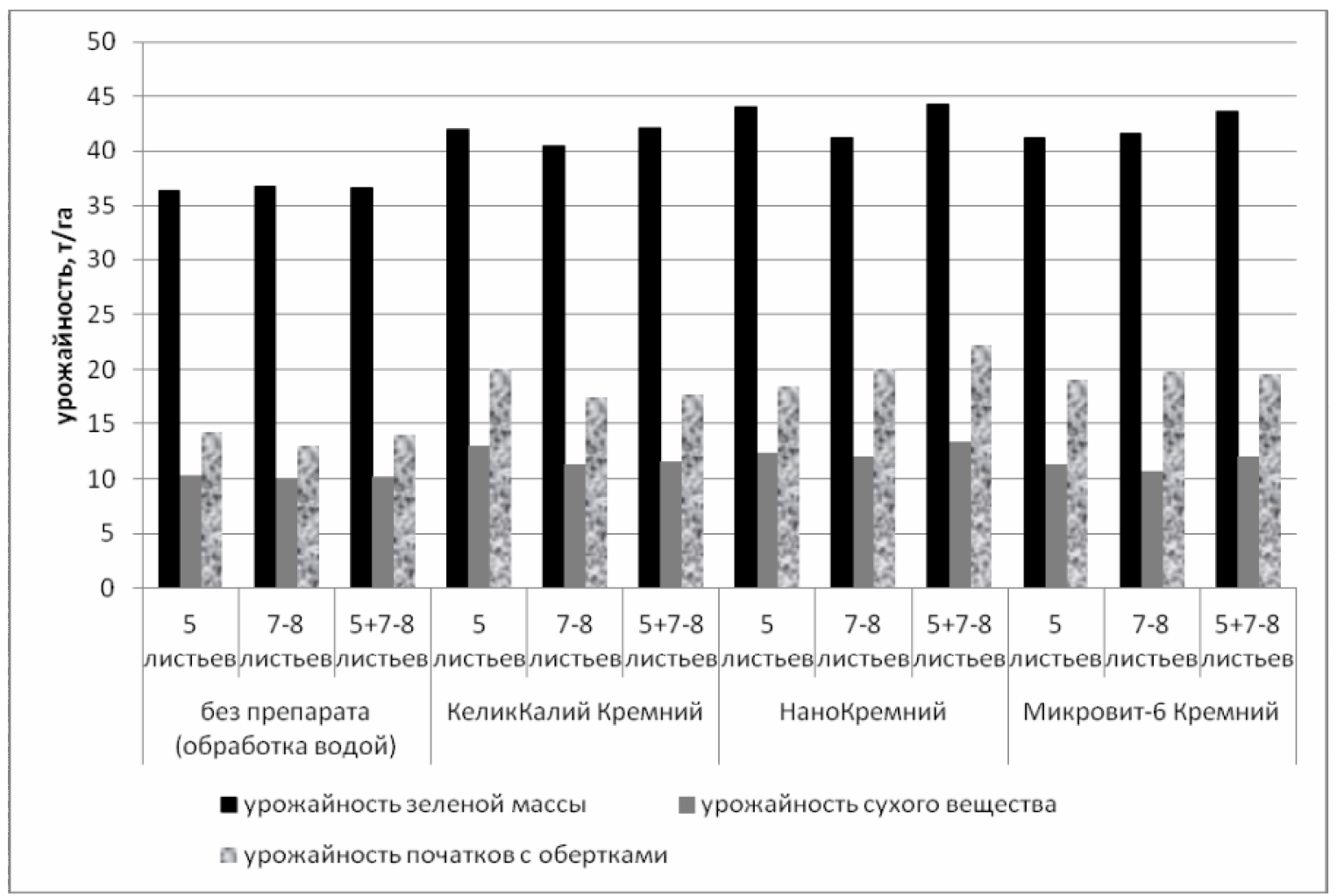

Влияние вида и срока обработки кремнийсодержащими препаратами на урожайность кукурузы, среднее за 2018-2019 ге.

Нива Поволжья $\quad$ № 1 (54) фревраль 2020 
кремнием составил 8,1-18,7 \% при небольшом преимуществе НаноКремния.

Урожайность кукурузы зависит от количества растений, занимающих посевную площадь и от массы каждого растения. Установлено, что в оба года проведения опыта более мощные растения сорормировались в вариантах с листовой обработкой посевов кукурузы препаратом НаноКремний в фразу пяти листьев и двукратном опрыскивании. В этих вариантах увеличение массы растения, по сравнению с вариантами без препарата, составило 110-112 г или 19,7-22,0\%. При обработке в фазу семи-восьми листьев кукурузы прирост составил 63 г или 11,0\%. Применение препарата Келик Калий-Кремний в фазу пяти листьев кукурузы дало прибавку 79 г или $13,9 \%$. Применение в фразу семи-восьми листьев кукурузы способствовало увеличению массы растения на 56 г или 10,5\%, а при двукратной обработке - на 89 г или 16,3 \%. Использование Микровит-6 Кремний по эффрективности было равноценным Келик Калий-Кремний, прирост варьировал от 11,6\% при обработке в фразу пяти листьев, до 19,0 \% при бинарном использовании препарата. В оба года исследований получена достоверная прибавка массы одного растения при применении кремнийсодержащих препаратов, однако по срокам обработки существенной разницы не выявлено.

Анализ урожайных данных показал, что в оба года исследований лучшие показатели по сбору зеленой массы получены при использовании НаноКремния. Видимо, это связано с тем, что при использовании НаноКремния растения дополнительно получают микроэлементы, такие как железо, медь и цинк. Следует отметить, что более эффрективной была обработка в фразу пяти листьев кукурузы и двукратное применение, которые обеспечили прирост урожайности фритомассы 20,6-21,0\%, по сравнению с вариантами без препарата (рисунок). Немного уступает по эффрективности препарат Микровит-6 Кремний, обеспечивший увеличение сбора зеленой массы 12,419,3 \%. Фолиарная обработка Келик КалийКремний способствовала росту урожайности зеленой массы на 3,7-5,7 т/га или 10,5$15,7 \%$.

Однако только по урожайности зеленой массы трудно сделать вывод о преимуществах применения того или иного препарата. Большое значение для получения качественного силоса имеет и содержание су- хого вещества в растении. Как показали полученные результаты, в 2018 г. при применении кремнийсодержащих препаратов отмечена тенденция снижения влажности зеленой массы. В условиях вегетации 2019 г. использование для внекорневой обработки Келик Калий-Кремний и Микровит-6 Кремний, наоборот, несколько снижало накопление сухого вещества, а в вариантах с НаноКремнием отмечено снижение влажности фитомассы.

Проведенные учеты урожайности сухого вещества показали, что при недостатке активных температур в условиях 2018 г. действие всех изучаемых препаратов, независимо от срока обработки, было примерно равным, а в более теплообеспеченном 2019 г. лучшие результаты получены при применении НаноКремния. В среднем за два года испытаний наибольший выход сухого вещества обеспечил вариант с двукратной обработкой посевов НаноКремнием, прирост составил 3,2 т/га или 31,4\%. Фолиарная обработка им в фазу пяти и семи-восьми листьев кукурузы привела к росту урожайности сухого вещества на 18,8$20,4 \%$ по сравнению с обработкой водой. Применение Келик Калий-Кремний в фразу пяти листьев было равноценным НаноКремнию, а при двукратном опрыскивании и обработке в фразу семи-восьми листьев получена прибавка в полтора-два раза меньше. Внекорневая обработка Микровит6 Кремний наибольший прирост обеспечила при двукратном применении - 1,8 т/га.

По сбору початков с обертками больших различий по препаратам не выявлено, при их применении прибавка составила 3,7-8,3 т/га или 26,4-54,0 \% к вариантам с обработкой водой.

\section{Заключение}

Проведенные исследования показали, что более мощные растения сформировались в вариантах с фолиарной обработкой посевов кукурузы препаратом НаноКремний в фазу пяти листьев и двукратном опрыскивании. Увеличение массы одного растения, по сравнению с вариантами без препарата, составило 110-112 г или 19,722,0 \%. Некорневая обработка НаноКремнием в фазу пяти листьев кукурузы и двукратное применение обеспечили прирост урожайности фритомассы 20,6-21,0 \% по сравнению с вариантами без препарата. Наибольший выход сухого вещества обеспечил вариант с двукратной обработкой посевов НаноКремнием, прирост составил 3,2 т/га. 


\section{Лumepamypa}

1. Ермолаев, А. А Кремний в сельском хозяйстве / А. А. Ермолаев // Химия в сельском хозяйстве. - 1987. - № 6. - С. 45-47.

2. Усанова, 3. И. Эффективность применения новых видов удобрений и наноматериала в технологии возделывания овса / 3. И. Усанова, А. С. Васильев // Достижения науки и техники АПК. - 2012. - № 8. - С. 19-22.

3. Матыченков, И. В. Взаимное влияние кремниевых, фосфорных и азотных удобрений в системе почва-растение: автореферат диссертации кандидата биологических наук / И. В. Матыченков. - Москва, 2014. - 20 с.

4. Влияние оптимизации кремниевого питания на устойчивость ДНК ячменя / Е. А. Бочарникова, Е. П. Пахненко, В. В. Матыченков, И. В. Матыченков // Вестник Московского университета. Серия 17. Почвоведение. - 2014. - № 2. - С. 40-43.

5. Матыченков, В.В.Влияние кремниевых удобрений на растения и почву / В. В. Матыченков, Е. А. Бочарникова, Я. М. Аммосова // Агрохимия. -2002. - № 2. - С. 86-93.

6. Опыт применения отечественного удобрения нанокремний на технических сортах винограда в условиях Крыма / Н. В. Алейникова, Н. А. Якушина, Е. С. Галкина [и др.] // Виноградарство и виноделие. - 2016. - Т. 46. - С. 35-38.

7. Бородин, Д. Б. Эффрективность применения нанокремния в посевах гороха / Д. Б. Бородин, А. А. Хорошилов, С. А. Фролова // Иновационные технологии и технические средства для АПК: Материалы международной научно-практической конференции молодых ученых и специалистов. - Воронеж, 2016. - С. 79-83.

8. Изучение действия нанокремния на фотосинтетическую продуктивность яровой пшеницы / Н. Е. Павловская, Д. П. Бородин, А. А. Хорошилова, И. В. Яковлева // Вестник Алтайского государственного аграрного университета. - 2017. - № 7 (153). - С. 12-18.

9. Першин, Б. М. Кремний и продуктивность риса в Приморском крае / Б. М. Першин, А. Н. Першина, Л. М. Егорина // Агрохимия. - 1995. - № 10. -С. 68-74.

10. Янишевская, O. JL Влияние кремния, марганца и хрома на продуктивность и некоторые показатели качества товарной продукции овощных культур / О. Л. Янишевская, Б. А. Ягодин // Агрохимия. - 2000. - № 5. - С. 47-51.

11. Садвакасов, С. К. К вопросу о фризиологической роли кремния в питании растений кукурузы / С. К. Садвакасов, М. Шахджахан, А. П. Иванов // Проблемы питания и использования удобрений в современных условиях. - Минск, 2000. - С. 45-48.

12. Методические рекомендации по проведению полевых опытов с кукурузой. - Днепропетровск, 1980. - 54 с.

13. Доспехов, Б. А. Методика опытного дела (с основами статистической обработки результатов) / Б. А. Доспехов. - Москва: Агропромиздат, 1985. - 351 с.

14. Cherif, M. Defense responses induced by soluble silicon in cucumber roots infected by Pythium spp. / M. Cherif, A Asselin, R. R. Belanger // Phytopathology. - 1994. - V. 84. - № 3. - P. 236-242.

15. Datnoff, L. E. Silicon fertilization for disease management of rice in Florida. / L. E. Datnoff, C. W, Deren, G. H. Snyder // Crop. Protect. - 1997. - V. 16. -№ 6. - P.525-531.

16. Effects of silicon on transpiration and leaf condidance in rice plants (Oryza sativa) / S. Agarie, H. Uchida, W. Agata [et al.] // Plant Product. Sc. - 1998. - V. 1. - № 2. - P. 89-546.

17. Effect of nanoparticles on seed germination andseedling growth of Boswellia ovalifoliolata an endemic and endangered medicinal tree taxon / N. Savithramma, S. Ankanna, G. Bhumi // Nano Vision. - 2012. - V. 2. - P. 61-68.

18. Silica nanoparticles for increased silica availability in maize (Zea mays L.) seeds under hydroponic conditions / R. Suriyaprabha [et al.] // Curr Nanosci. - 2012. - V. 8. - P. 902-908.

UDC 633.15+631.81.095.337

DOI: $10.36461 / \mathrm{NP} .2020 .54 .1 .002$

\section{EFFECT OF SILICON CONTAINING PRODUCTS ON FORMATION OF CORN YIELD}

\section{S. A. Semina, Doctor of Agricultural Sciences, professor; I. V. Gavryushina, Candidate} of Biological Sciences, associate professor; E. V. Nikulina, graduate student

Federal State Educational Institution of Higher Education Penza State Agrarian University, Russia, $t$.

(8412)628-151, e-mail: seminapenza@rambler.ru

The article presents the results of studies on the effect of various types of silicon containing products on formation of corn yield, depending on the timing of nonroot treatment. The greatest growthpromoting effect was noted with a double treatment of corn crops with NanoSilicon. The growth compared to the variant with water treatment was $33 \mathrm{~cm}$. When Kelik Potassium-Silicon was used, taller plants formed after foliar treatment in the five-leaf phase, the growth to the variant without the product was $19 \mathrm{~cm}$. In the variant with Microvit- 6 Silicon, the height of the plants was more by $14-18 \mathrm{~cm}$ compared to plants sprayed with water. 
The increase in the number of developed cobs during the foliar treatment with silicon products was 8.1-18.7 \% with a slight advantage of NanoSilicon. More powerful plants were formed in the variants with foliar treatment of corn crops with Nano Silicon in the phase of five leaves and double spraying; the increase in the mass of one plant, compared to the variants without the product, amounted to $110-112 \mathrm{~g}$ or $19.7-22.0 \%$. More effective was the treatment with NanoSilicon in the phase of five corn leaves and double application, which ensured an increase in the yield of phytomass of $20.6-21.0 \%$ compared with the variants without the product. The Microvit- 6 Silicon product is slightly inferior in effectiveness, which ensured a 12.4-19.3\% increase in the yield of green mass. The foliar treatment of Kelik PotassiumSilicon contributed to an increase in the yield of green mass by 3.7-5.7 t/ha or $10.5-15.7 \%$. The highest yield of dry matter was ensured by the variant of double spraying of crops with NanoSilicon, an increase of $3.2 \mathrm{t} / \mathrm{ha}$.

Keywords: corn, silicon, biometric indicators, green mass, cobs, yield.

\section{Reference:}

1. Ermolaev, A. A. Silicon in agriculture/A. A. Ermolaev // Chemistry in agriculture. - 1987. - No. 6. P. 45-47.

2. Usanova, Z. I. Effectiveness of the use of new types of fertilizers and nanomaterial in the technology of oat cultivation/Z. I. Usanova, A. S. Vasiliev // Achievements of science and technology of the agro-industrial complex. - 2012. - No. 8. - P. 19-22.

3. Matychenkov, I. V. Mutual influence of silicon, phosphorus and nitrogen fertilizers in the soilplant system: abstract of the dissertation of the candidate of biological sciences/l. V. Matychenkov. Moscow, 2014.- 20 p.

4. Effect of optimization of silicon nutrition on the stability of barley DNA/E. A. Bocharnikova, E. P. Pakhnenko, V. V. Matychenkov, I. V. Matychenkov // Bulletin of Moscow University. Series 17. Soil Science. - 2014. - No. 2. - P. 40-43.

5. Matychenkov, V. V. Effect of silicon fertilizers on plants and soil/V. V. Matychenkov, E. A. Bocharnikova, Y. M. Ammosova // Agricultural chemistry. -2002. - No. 2. - P. 86-93.

6. Experience of using domestic fertilizer nanosilicon on industrial grape varieties in the conditions of Crimea/N. V. Aleinikova, N. A. Yakushina, E. S. Galkina [et al.] // Viticulture and winemaking. - 2016. T. 46. - P. 35-38.

7. Borodin, D. B. Effectiveness of nanosilicon use in pea crops/D. B. Borodin, A. A. Khoroshilov, S. A. Frolova // Innovative technologies and technical means for the agro-industrial complex: Materials of the international scientific-practical conference of young scientists and specialists. - Voronezh, 2016.- P. 79-83.

8. The study of the action of nanosilicon on the photosynthetic productivity of spring wheat / N. E. Pavlovskaya, D. P. Borodin, A. A. Khoroshilova, I. V. Yakovleva // Bulletin of the Altai State Agrarian University. - 2017. - No. 7 (153). - P. 12-18.

9. Pershin, B. M. Silicon and rice productivity in the Primorsky Kray/B. M. Pershin, A. N. Pershina, L. M. Egorina // Agricultural chemistry. - 1995. - No. 10. - P. 68-74.

10. Yanishevskaya, O. L. Effect of silicon, manganese and chromium on productivity and some indicators of the quality of marketable products of vegetable crops/O. L. Yanishevskaya, B. A. Jagodin // Agricultural chemistry. - 2000. - No. 5. - P. 47-51.

11. Sadvakasov, S. K. On the physiological role of silicon in the nutrition of corn plants / S. K. Sadvakasov, M. Shahjahan, A. P. Ivanov // Problems of nutrition and use of fertilizers in modern conditions. Minsk, 2000.- P. 45-48.

12. Guidelines for conducting field trials with corn. - Dnepropetrovsk, 1980.- $54 \mathrm{p}$.

13. Dospekhov, B. A. Experimental technique (with the basics of statistical processing of results)/B. A. Dospekhov. - Moscow: Agropromizdat, 1985.- 351 pp.

14. Cherif, M. Defense responses induced by soluble silicon in cucumber roots infected by Pythium spp./M. Cherif, A Asselin, R. R. Belanger // Phytopathology. - 1994. - V. 84. - № 3. - P. 236-242.

15. Datnoff, L. E. Silicon fertilization for disease management of rice in Florida./L. E. Datnoff, C. W, Deren, G. H. Snyder // Crop. Protect. - 1997. - V. 16. -№ 6. - P.525-531.

16. Effects of silicon on transpiration and leaf condidance in rice plants (Oryza sativa)/S. Agarie, H. Uchida, W. Agata [et al.] // Plant Product. Sc. - 1998. - V. 1. - № 2. - P. 89-546.

17. Effect of nanoparticles on seed germination andseedling growth of Boswellia ovalifoliolata an endemic and endangered medicinal tree taxon/N. Savithramma, S. Ankanna, G. Bhumi // Nano Vision. - 2012. - V. 2. - P. 61-68.

18. Silica nanoparticles for increased silica availability in maize (Zea mays L.) seeds under hydroponic conditions/R. Suriyaprabha [et al.] // Curr Nanosci. - 2012. - V. 8. - P. 902-908. 